\title{
PERAN PEREMPUAN DALAM BUDAYA MARITIM WAROPEN (The Role of Women in the Culture of Maritime in Waropen)
}

\author{
Rini Maryone \\ Balai Arkeologi Papua \\ Jalan Isele, Kampung Waena, Distrik Heram, Kota Jayapura 99358 \\ e-mail: Rinimaryone1972@gmail.com
}

\section{INFO ARTIKEL}

Histori Artikel

Diterima: 1 Agustus 2017

Direvisi: 8 Agustus 2017

Disetujui: 30 Oktober 2017

\section{Keywords: \\ Roles, \\ Women, \\ Tradition, \\ Maritime, \\ Waropen}

\section{Kata kunci:}

Peran,

Perempuan,

Budaya,

Maritim,

Waropen

\section{ABSTRACT}

In Waropen livelihood, women in connected maritime tradition play roles in providing food for their family. In related to the title, there are some problems deal with the women's roles in Waropen maritime tradition that can be formulated as follows: How are the roles of women in Waropen maritime tradition, what values revealed in maritime tradition. The research applies etnoarcheolgical approach by using some techniques: bibliographical study, observation, and interview. Those collected data are then described, analyzed, interpreted, and concluded. The results show that there are three main livelihood, i.e., processing sagoo, cathing fish (by men), cathing crabs (by men), and gathering seashells (by men). While women's roles follow the knowledge system of maritime tradition: time, season, wind, and stars. To go to the location of sagoo processing, shrimps and seashells gathering, Waropen women use canoes without leeboard. In local language it is called sewado. Through the roles of Waropen women in maritime tradition, there are some beneficial socio-cultural values, i.e. being religious, corporation, independence, discipline, hard work, creativity, and care to nature.

ABSTRAK
Peran serta perempuan Waropen dalam sistem mata pencaharian
hidup berkaitan dengan tradisi maritim, perempuan bertanggung
jawab penuh untuk menyiapkan makanan bagi keluarganya.
Berkaitan dengan judul, ada beberapa permasalahan yang
muncul berkaitan dengan peran perempuan dalam budaya maritim
Waropen, yang dapat dirumuskan sebagai berikut: Bagaimana peran
perempuan dalam budaya maritim di Waropen?, nilai-nilai apa saja
yang terkandung dalam budaya maritim tersebut?. Penelitian ini
menggunakan pendekatan etnoarkeologi dengan menggunakan
beberapa teknik yaitu: studi pustaka, observasi, wawancara. Setelah
semua data yang dibutuhkan terkumpul kemudian dideskripsikan,
dianalisis dan diinterpretasikan, dan ditarik suatu kesimpulan.
Hasil penelitian menunjukkan ada tiga macam mata pencaharian
utamanya yaitu meramu sagu, menangkap ikan (dilakukan oleh laki-
laki), menangkap kepiting dan mengumpulkan atau kerang, berburu
(dilakukan oleh perempuan). Sementara itu, perempuan Waropen
mengikuti sistem pengetahuan budaya maritim seperti sistem
pengetahuan mengenai waktu, musim, angin dan bintang. Untuk ke
lokasi tempat mencari seperti menokok sagu, mencari keping, udang
dan bia, perempuan Waropen menggunakan perahu tak bercadik
yang disebut dengan sewado. Melalui peran perempuan Waropen
dalam budaya maritim, termuat nilai-nilai sosial-budaya yang berguna
dalam kehidupan, yaitu nilai religius, gotong royong atau kerjasama,
kemandirian, disiplin, kerja keras, kreatif, dan peduli lingkungan.




\section{PENDAHULUAN}

Kemampuan perempuan sering diragukan terutama dalam melakukan kegiatan-kegitan pada bidang ekonomi atau sosial-budaya dikeluarga atau di masyarakat. Salah satu faktor penyebabnya adalah kondisi biologis perempuan terutama dikaitkan dengan fungsi reproduksi. Demikian halnya dalam pengasuhan anak secara universal cenderung disebut sebagai peran eklusif perempuan (Berry, 1999 : 135). Fungsi reproduksi dan tanggung jawab pengasuhan anak sering dianggap sebagai penghambat bagi kegiatan perempuan dibidang lain terutama yang berkaitan di luar rumah. Dalam kenyataannya dimasyarakat reproduksi tidak terjadi setiap waktu. Demikian halnya dengan pengasuhan anak dapat dibantu oleh orang lain, misalnya kerabat atau anak-anak yang sudah besar, sehingga mampu melakukan kegiatankegiatan di luar rumah.

Perbedaan pandangan berkaitan dengan peranan perempuan dan lakilaki di masyarakat pada umumnya dikaitkan dengan peran gender. Gender merupakan konstruksi dan tatanan sosial mengenai berbagai perbedaan antara jenis kelamin yang mengacu kepada relasi-relasi sosial antara perempuan dan laki-laki atau suatu sifat yang telah ditetapkan secara sosial maupun budaya (Susanti, 2000 : 3-4).

Selanjutnya disebutkan bahwa para gender dibedakan dari peran kodrati, yaitu peran yang didasarkan pada kodrat. Peran gender sebagai peran yang ditetapkan secara budaya terbuka untuk dipertukarkan antara laki-laki dan perempuan, sementara peran kodrati, adalah peran yang tidak dapat ditukarkan karena sudah demikian diciptakannya, seperti hamil, melahirkan, dan menyusui pada perempuan. Dengan demikian peran gender tidak bersifat universal, tetapi berubah dan berbeda karena dipengaruhi oleh idiologi, ekonomi, adat, agama, dan sosial budaya, etnik, waktu, tempat serta kemajuan iptek. Kemudian Herskovits memandang peran gender itu sebagai perkembangan historis kebanyakan tradisi-tradisi khas yang mengatur kehidupan bangsa tertentu (Harskovits dalam Haviland, 1988 : 42).

Lebih lanjut (Susanti, 2000 : 5) mengemukakan bahwa hal yang wajar, sebab setiap budaya dan komunitas mempunyai berbagai ekspresi yang khas. Perbedaan gender baru menjadi masalah jika perbedaan itu mengakibatkan ketimpangan perlakukan dalam masyarakat serta ketidakadilan dalam hak kesempatan bagi laki-laki dan terutama bagi perempuan.

Mengacu kepada judul di atas mengenai peran perempuan dalam budaya maritim di Waropen tidak terlepas dari perempuan itu sendiri ditengah-tengah keluarga masyarakat dan adat yang berlaku di dalam kehidupannya. Demikian halnya dengan peran perempuan Waropen, dimana perempuan Waropen dituntut dapat mengerjakan berbagai pekerjaan untuk menujang kelangsungan hidup 
keluargannya dan masyarakat sosial lainnya. Di dalam adat istiadat suku Waropen, perempuan bertanggung jawab untuk memenuhi kebutuhan sandang dan pangan keluarga. Berdasarkan hal tersebut maka ada pembagian kerja yang jelas diantara lakilaki dan perempuan, sesuai dengan adat istiadat yang berlaku di dalam kehidupan mereka.

\section{Masyarakat}

menghendaki perempuan

Waropen pendukung suami atau sebagai laki-laki.

Perempuan harus dapat menghasilkan panen (hasil kebun), ikan, bia, dan membudidayakan sagu yang melimpah. Dia juga dituntut mampu mengerjakan pekerjaan rumah tangga lainnya, serta melayani keluarganya. Karena fisik yang kuat, seorang perempuan mampu bekerja keras dan dapat memberikan kontribusi makanan yang melimpah kepada pertemuan-pertemuan adat.

Masyarakat Waropen dikenal sebagai masyarakat yang masih hidup dalam kesederhanaan dengan kebudayaannya yang asli. Hampir semua kebutuhan dan peralatan yang digunakan dibuat secara alami dari bahan yang ada di sekitar mereka. Matapencaharian hidup dapat dikatakan sebagian masih bergantung pada alam.

Bila dikaitkan dengan keadaan lingkungan dan budaya maritim di Waropen, wilayah Waropen merupakan wilayah yang memiliki sumberdaya perairan yang beraneka ragam, terdiri atas berpuluh-puluh sungai besar dan kecil yang penuh dengan ikan, udang kepiting dan bahan pangan lainnya, sehingga mempengaruhi segala bentuk mata pencaharian mereka (Sanggenafa, $1993: 15)$.

Pada masa lalu kehidupan masyarakat Waropen banyak berkaitan dengan air (sungai dan laut). Masyarakat Waropen mengenal budaya maritim yang dikaitkan dengan sistem pengetahuan, mengenai waktu, mempunyai konsepsi yang sangat jelas, karena pengetahuan ini berhubungan erat dengan kegiatan pencaharian (sami) dan pelayaran lokal. Tentang pengetahuan seperti ini, penduduk setempat mengenal secara baik tentang ratama dan wado. Ratama dalam pengetahuan tentang waktu diartikan dengan musim angin timur. Dan dalam situasi seperti ini lautan disekitar menjadi tenang. Awal dari keadaan ini selalu ditandai dengan munculnya burung raga (gheea) dari hutan pedalaman ke daerah pantai. Pada saat seperti ini, dianggap paling baik untuk melakukan kegiatan sami, seperti menangkap ikan di laut atau sungai, mengumpulkan kerang dan kepiting, berburu dan sebagainya. Selain itu justru dinanti-nantikan oleh penduduk setempat terutama orang-orang tua untuk melakukan perjalanan jauh dengan menggunakan gha somandhu ke daerahdaerah lain, malah berlayar sampai ke Kabupaten Manokwari. Menurut perhitungan (penanggalan) penduduk setempat, ratama ini berlangsung antara bulan April sampai dengan bulan Juli.

Wado dalam pengetahuan tentang waktu diartikan dengan musim 
angin barat. Dalam situasi seperti ini, laut disekitar berombak. Awal dari musim ini ditandai dengan masuknya ghea dari pantai ke hutan pedalaman. Menurut penanggalan penduduk setempat, wado berlangsung antara bulan Agustus sampai dengan bulan Maret. Pada saat seperti itu, dianggap tidak tepat untuk melakukan sami maupun perjalanan ke daerah-daerah lain. Malah ditunggutunggu oleh orang-orang tua dirantau untuk melakukan perjalanan kembali. Dengan wado ini, kegiatan ekonomi lebih banyak dialihkan kepada menokok sagu, berburu dan kegiatan-kegiatan di rumah. Selain pengetahuan tentang waktu di atas, penduduk setempat juga mengetahui dengan teliti dan jelas tentang perubahan-perubahan pasang surut air di laut maupun di kali. Dan pengetahuan berhubungan erat dengan kegiatan sami.

Pengerahuan tentang bintang (Uma) berkaitan erat dengan kegiatan sami, penggunaan pengetahuan ini dengan melihat kepada bintang-bintng seperti gugusan/rasi bintang pari (sawa dan samamai), gugusan/rasi bintang kecil (ghowiritara), bintang malam (ombaibai) dan bintang pagi (sapari). Untuk menentukan musim, diperhatikan gugusan bintang sawa dan sasamai serta rasi bintang ghowiritara. Apabila gugusan bintang sawa dan sasamai muncul (sawai sara) biasanya ini dianggap sebagai waktu yang paling tepat untuk melakukan kegiatan sami maupun pelayaran lokal. Sebaliknya, apabila sawa dan sasamai berada dalam posisi menurun (sawai suni), merupakan waktu yang tidak cocok/tepat untuk melakukan kegiatan sami maupun pelayaran lokal, karena pada saat itu bertiup angin kencang (wado). Untuk pelayaran lokal pada waktu malam hari diperhatikan bintang ombaiba dan bintang sapari. Bintang ombaiba merupakan pedoman arah barat, sedangkan bintang sapari merupakan pedoman arah timur. (Refasi dkk, $1982: 70$ )

Pengetahuan tentang angin (ghama) bermanfaat untuk kepentingan pelayaran lokal dan kegiatan sami. Pengetahuan terhadap angin berhubungan erat dengan pasang surut air laut/kali, perbedaan siang dan malam serta perbintangan. Sejenis angin setempat adalah angin timur, (raghama), angin barat (mararo) serta angin lokal, yakni angin darat (fefe) dan angin laut (ghanasai). Untukkepentingan pelayaran lokal, digunakan angin timur (raghama). Sebaliknya pada saat bertiupnya angin barat (mararo) digunakan untuk kembali dari rantau. Untuk kepentingan menangkap ikan, digunakan angin darat (fefe) sebagai pengantar ke laut, dan sebaliknya angin laut (ghanasai) untuk pulangnya (Refasi, dkk, 1982 : 71).

Dalam aktivitas mata pencaharian hidup, untuk memudahkan perempuan Waropen pergi ke dusun sagu dan mencari ikan di laut atau sungai dan mengumpulkan kerang, mereka juga sangat membutuhkan alat transportasi berupa perahu. Membuat perahu merupakan keterampilan yang dimiliki oleh kaum pria tertentu. Ada dua 
macam perahu yang dibuat, yaitu perahu bercadik ( $g h a$ ) dan perahu tidak bercadik atau perahu sampan (sawodo). Bahan pembuat perahu ini diperoleh dari hutan setempat, yang terdiri dari jenisjenis kayu finang (binano), kayu merah dan kayu minyak (sigha). Hasil yang diperoleh selain untuk dipakai, juga dijual. Sering dipakai pula sebagai alat pembayaran mas kawin (kayu merah atau maigheano).

Berkaitan dengan judul diatas mengenai peran perempuan dalam budaya maritim, dimana mereka masih memanfaatan alam di sekitar mereka dan masih menggunakan teknologi sederhana, dan juga mengikuti budaya maritim yaitu sistem pengetahuan mengenai waktu, perbintangan dan angin yang merupakan warisan nenek moyang.

Berkaitan dengan hal tersebut ada beberapa permasalahan yang muncul berkaitan dengan peran perempuan dalam budaya maritim di Waropen, yang dapat dirumuskan sebagai berikut: bagaimana peran perempuan dalam budaya maritim di Waropen? bagaimana nilai-nilai yang terkandung di dalam budaya maritim tersebut? Dengan mengacu pada latar belakang dan permasalahan di atas, maka yang menjadi tujuan dalam penelitian ini adalah untuk mendeskripsikan peran perempuan dalam budaya maritim serta nilai-nilai yang terkandung di dalam budaya maritim Waropen.

Metode yang digunakan dengan menggunakan pendekatan etnoarkeologi dengan menggunakan beberapa cara yaitu: studi pustaka, yaitu dengan melakukantelaahbeberapabukumaupun literatur yang berkaitan dengan objek kajian, baik yang berhubungan langsung dengan wilayah penelitian maupun yang berkaitan dengan teori maupun metodenya. Observasi, melakukan pengamatan langsung terhadap obyek penelitian, yaitu menyangkut peran perempuan dalam budaya maritim di Kampung Apainabo, Distrik Urei-Faysei, Kabupaten Waropen. Perekaman data dilakukan dengan mengambil gambar obyek penelitian berupa bendabenda yang berkaitan dengan budaya maritim serta lingkungan sekitar yang mendukung budaya tersebut.

Dalam penelitian arkeologi khususnya etnoarkeologi, wawancara merupakan salah satu pengumpulan data yang paling efektif (Redaksi, 2008: 26). Dalam penelitian ini dilakukan wawancara mendalam dengan penduduk, khususnya perempuan Waropen yang menyangkut mata pencaharian hidup dan pengetahuan tentang nilai-nilai budaya maritim yang mereka miliki.

\section{HASIL DAN PEMBAHASAN}

Secara adat, masyarakat Waropen sudah mempunyai pandangan tersendiri terhadap keberadaan perempuan. Pandangan ini dapat diinterpretasikan sebagai standardisasi masyarakat terhadap keberadaan dan peran perempuan Waropen 
secara keseluruhan. Seorang laki-laki menginginkan perempuan yang dapat bekerja keras dan dapat melahirkan banyak anak, baik anak laki-laki maupun anak perempuan (Knauft, 2002 dalam Modouw, 2008 : 441). Masyarakat Waropen menyukai perempuan yang berfisik kuat. Kekuatan fisik perempuan Waropen dianggap sangat penting untuk mengatasi tuntutan kerasnya alam. Masyarakat Waropen percaya bahwa perempuan yang fisiknya kuat dapat melakukan pekerjaan yang besar.
Perempuan Waropen dituntut dapat mengerjakan berbagai pekerjaan untuk menunjang kelangsungan hidup keluarganya dan masyarakat sosial lainnya. Dia harus dapat menghasilkan panen (hasil kebun), ikan, kerang, dan membudidayakan sagu yang melimpah. Dia juga dituntut mampu mengerjakan pekerjaan rumah tangga lainnya, serta melayani keluarganya. Karena fisik yang kuat, seorang perempuan mampu bekerja keras dan dapat memberikan kontribusi makanan yang melimpah

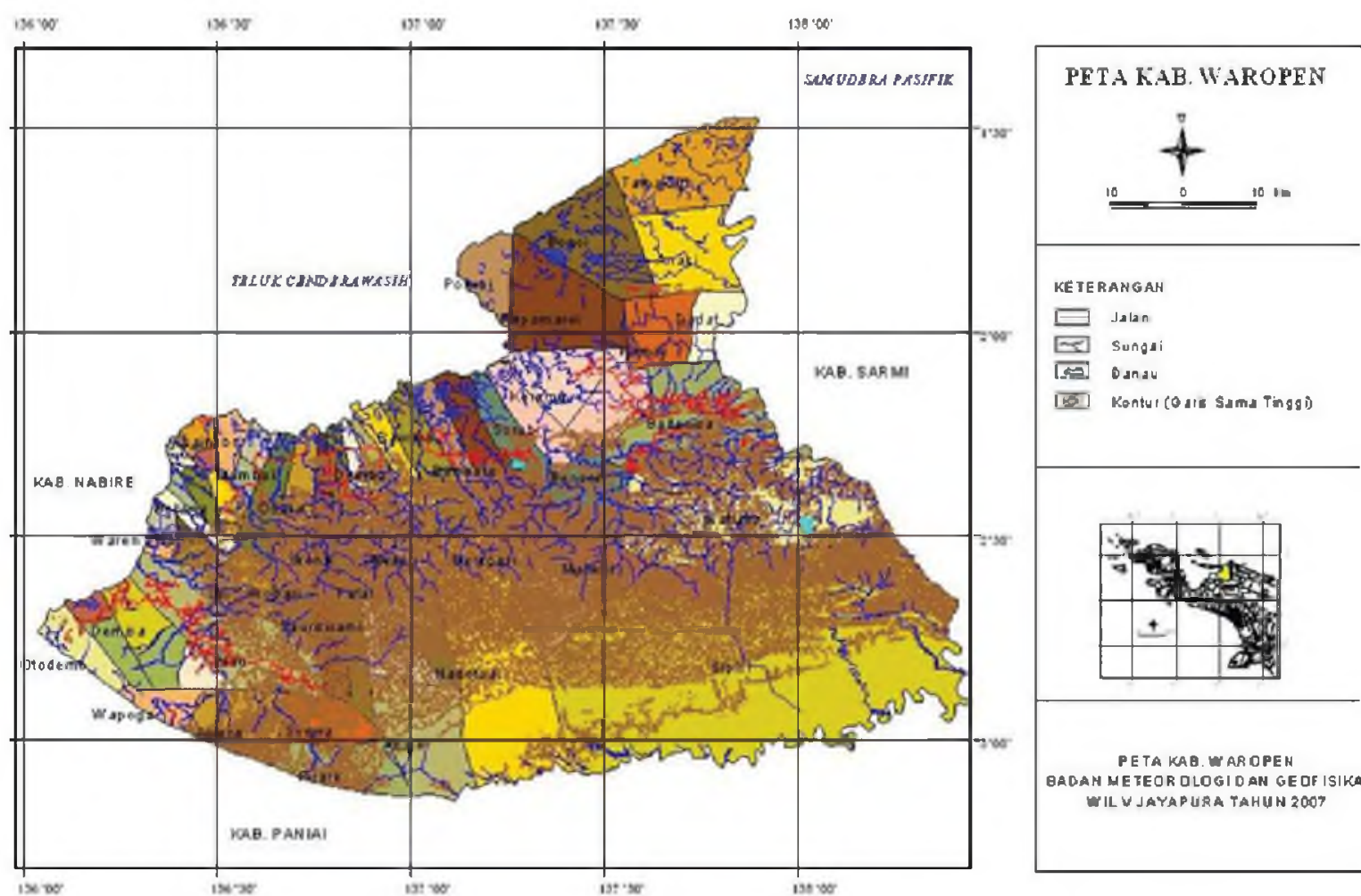

kepada pertemuan adat. Pertemuan adat adalah tempat berkumpulnya para tua-tua adat yang membahas berbagai permasalahan adat. Pada acara tersebut, biasanya disuguhkan berbagai makanan. Peran perempuan disini adalah mampu memberikan kontribusi makanan yang besar sehingga, tempat pertemuan adat dipenuhi dengan makanan. Tampak bahwa perempuan Waropen banyak dinilai masyarakat melalui kemampuannya bekerja, penghasilannya, serta kekuatan fisiknya. Wilayah kediaman suku Waropen secara ekologis terdiri dari ekologi hutan bakau, ekologi hutan rawa dan ekologi hutan pegunungan. Daerah pesisir Waropen seluruhnya terdiri 
dari hutan bakau (rizophora avicennia) yang padat (Sanggenafa, 1993 : 30). Dengan melihat kondisi ekologi tersebut maka membentuk pula sistem mata pencaharian perempuan Waropen.

Masyarakat Waropen merupakan masyarakat yang dalam kehidupan perekonomian sangat bergantung dan dipengaruhi oleh alam lingkungannya. Seperti yang dapat kita lihat pada sistem mata pencaharian khususnya yang dilakukan oleh perempuan Waropen, mereka masih menunjukan pola kehidupan tradisional.

\section{BENTUK-BENTUK MATA PENCAHARIAN PEREMPUAN WAROPEN}

Adapun bentuk-bentuk mata pencaharian perempuan Waropen di daerah Urei-Faysei adalah:

Meramusagumerupakankegiatan terpenting dalam kehidupan orang Waropen sehingga untuk melakukan kegiatan tersebut ada aturan-aturan yang harus ditaati, baik yang berkaitan dengan kegiatan menokok maupun dalam hal membudidayakannya.

Pantangan-pantangan tersebut misalnya bagi seorang wanita yang sedang menstruasi tidak diperbolehkan ikut dalam kegiatan menokok sagu, karena akan berdampak buruk jika hal tersebut dilanggar. Disamping itu juga dalam hal menebang pohon sagu, jika batang yang ditebang jatuh ke arah luar hutan sagu maka pada saat pemotongan pelepah yang pertama harus segera ditarik ke dalam hutan dengan tujuan agar pati yang ada tidak lari keluar. Aturan lain seperti dalam kegiatan membudidayakan pohon sagu dimana bagi orang yang menanam pohon sagu, orang tersebut harus bersih, tidak boleh bersetubuh dengan isterinya atau suaminya, saat menanam harus berada pada arah yang berlawanan dengan sinar matahari untuk menghindari bayangannya masuk ke dalam lubang. Jika hal itu terjadi maka si penanam akan sakit. Setelah menanam orang tersebut tidak boleh mandi bahkan hasil panennya yang pertamapun si penanam tidak boleh memakannya. Aturan-aturan tersebut harus tetap ditaati untuk suatu keberhasilan.

Kegiatan meramu sagu biasanya dilakukan oleh keluarga batih untuk memenuhi kebutuhan sehari-hari. Pohon sagu yang dipilih dan siap untuk ditebang adalah yang telah berumur lebih kurang 8-10 tahun dan diperkirakan sudah mengandung banyak tepung. kegiatan meramu sagu dilakukan dengan menggunakan peralatan sederhana di samping tugas yang jelas berdasarkan pada kemampuan dan jenis kelamin. Biasanya untuk memperoleh hasil yang banyak, kegiatan menokok sagu dilakukan oleh perempuan dan wanita-wanita tua yang berpengalaman. Dalam menokok sagu ada pembagian tugas yang jelas antara laki-laki dan perempuan yaitu lakilaki bertugas menebang, memotong, membersihkan, dan menyiapkan tempat untuk meramas. Tugas perempuan 
melakukan kegiatan menokok, meramas dan membawa pulang hasil ke kampung. Namun demikian dalam suatu keadaan pekerjaan laki-laki bisa dilakukan oleh kaum perempuan dan sebaliknya. Satu batang pohon sagu dapat menghasilkan 100-150 kg tepung sagu basah. Sagu yang dihasilkan tersebut selain untuk dimakan sehari-hari, dan ada pulah yang dijual dan digunakan untuk kebutuhan selamatan dan upacara adat.

Tepung atau pati sagu biasanya diolah dengan cara dibuat bubur atau papeda (wawiro) dan dibakar atau sagu bakar (fiumbe). Pohon sagu memiliki banyak manfaat bagi manusia selain patinya yang diambil untuk dikonsumsi tetapi juga bagian lainnya seperti kulit batang, daun dan pelepahnya digunakan sebagai bahan bangunan dan alat untuk mengolah sagu itu sendiri.

Dalam proses meramu sagu ada beberapa macam peralatan yang diperlukan seperti: alatpenokoksagu, alat membelah atau tugal (rea), alat penadah (enggenda), parang (naibawa), kapak (mbano), alat peramas. Dalam proses pembuatan tepung sagu, dipergunakan alat-alat untuk memisahkan ampas sagu dengan tepungnya adalah sebagai berikut: tempat ramas (fai), penapis (rua), penyaring (ureba), penimba air (remaina), penjepit (fai ndoropa), alat ini berfungsi sebagai penjepit antara tempat peramas dan menyaring, terbuat dari pelepah sagu yang dibentuk menyerupai telinga, penopang (taperasa), penahan penapis (ghoda), noken (rowu). (Maryone, 2007).
Kegiatan menokok sagu bila dikaitkan dengan budaya maritim Waropen, mereka mengikuti pengetahuan mengenai wado dalam pengetahuan tentang waktu yang diartikan dengan musim angin barat, dalam situasi seperti ini, laut disekitar berombak, sehingga dengan wado ini, kegiatan ekonomi lebih banyak dialihkan kepada menokok sagu, dan kegiatankegiatan di rumah.

Pembagian tugas, antara lakilaki dan perempuan dimana untuk mengangkut sari tepung sagu adalah perempuan, untuk menampung sari pati sagu mempergunakan noken, dan alat transportasi di gunakan adalah perahu tak bercadik yaitu sewado, dengan menggunakan perhitungan waktu musim angin timur.

\section{MENANGKAP KEPITING DAN MENGUMPULKAN KERANG}

Kegiatan mencari ikan dilakukan oleh kaum laki-laki sedangkan menangkap kepiting dan mengumpulkan kerang dilakukan oleh kaum perempuan. Kegiatan menangkap kepiting dan mengumpulkan kerang dilakukan di daerah hutan bakau. Dalam kegiatan mata pencaharian perempuan Waropen tidak terlepas dari sistem sosial masyarakatnya, seperti kegiatan mancari dan mengumpulkan makanan untuk kepentingan selamatan maupun untuk pesta atupun upacara adat, biasanya dilakukan secara bersama-sama baik laki-laki dan perempuan sehingga hasil 
yang dibutuhkan terkumpul dalam waktu yang tidak terlalu lama dan kegiatan-kegiatan tersebut dapat segera dilaksanakan. Dalam aktivitas-aktivitas mata pencaharian perempuan Waropen tersebut tetap mempertimbangkan aturan adat yang berlaku.

Kegiatan ini dilakukan di hutan bakau yang tergenang saat air laut pasang dengan menggunakan sarana berupa perahu tidak bercadik (sewado), dan dengan menggunakan peralatan yang sangat sederhana. Perempuan Waropen juga dalam menangkap kepiting dan mengumpulkan kerang mengenai secara baik tentang ratama dan wado, dalam sistem pengetahuan/ budaya maritim. Ratama dalam pengetahuan tentang waktu diartikan dengan musim angin timur, situasi seperti ini lautan disekitar menjadi tenang. Awal dari keadaan ini selalu ditandai dengan munculnya burung raga (gheea) dari hutan pedalaman ke daerah pantai. Pada saat seperti ini, dianggap paling baik untuk melakukan kegiatan sami, seperti menangkap ikan di laut atau sungai, mengumpulkan kerang dan kepiting.

Peralatan yang digunakan untuk menangkap kepiting dan mengumpulkan kerang adalah berupa alat penggali (rekuwo), keranjang (baka), dan noken (rowu), khusus untukmenangkapkepiting digunakan juga pengait (dadakea atau emba) (Maryone, 2007 : 55). Hasil dari menangkap kepiting dan mengumpulkan kerang selain untuk komsumsi seharihari ada yang dijual atau ditukar (barter) serta untuk kebutuhan dalam suatu ritual tertentu. Jika hasil penangkapan kepiting dan kerang yang diperoleh banyak, maka untuk lebih tahan lama biasanya dipelihara dengan menjaga agar kepiting atau kerang tersebut tidak terkena air tawar maka dikeringkan, khusus untuk kerang yaitu dengan jalan mengeluarkan isinya dari cangkang kemudian dagingnya diasap hingga matang dan kering.

\section{NILAI-NILAI YANG TERDAPAT DALAM BUDAYA MARITIM PADA PEREMPUAN WAROPEN}

Kesempatan yang terbuka bagi perempuan Waropen untuk berkiprah khususnya dalam budaya maritim yang telah diuraikan di atas menggambarkan bahwa perempuan Waropen memiliki peran yang cukup penting di keluarga dan masyarakat, serta adat. Hal ini perempuan Waropen bertanggung jawab bersama-sama dengan kaum lakilaki mencari nafkah, saling mengisi satu dengan yang lain yang dapat menjadi acuan dalam membentuk keluarga dan masyarakat sejahtera.

Bila dikaitkan dengan budaya maritim Waropen terdapat nilai-nilai budaya yang dapat dipakai sebagai penguat jadi diri. Posisi budaya yang demikian penting dalam kehidupan masyarakat mengharuskan budaya menjadi sumber nilai-nilai dari pendidikan budaya dan karakter bangsa. Terkait hal tersebut terdapat sumber nilai yang dihasilkan dapat digunakan untuk pendidikan budaya dan karakter bangsa, 
yaitu nilai-nilai:

1. Religius: suatu sikap dan perilaku yang patuh dalam melaksanakan ajaran agama yang dianutnya, bekaitan dengan lingungan alam dimana alam yang menyediakan semua bahan alat untuk membuat perlengkapan peralatan hidup, mereka beranggapan bahwa lingkungan alam terdapat banyak kekuatan gaib yang harus ditakuti dan dihormati karena mengontrol kehidupan. Sehingga timbul nilai budaya yang aktif terhadap lingkungan alam.

2. Gotong royong atau kerja sama: Potensi masyarakat kampung yang tidak kalah pentingnya adalah gotong royong. Masyarakat kampung selalu mengedepankan gotong royong dalam lingkungan klen maupun kampung. Nilai sosiokultural seperrti inilah yang perlu mendapat perhatian, agar masyarakat dengan kesadaran sendiri ikut dalam pembangunan.

3. Kemandirian: kemampuan melakukan pekerjaan sendiri dengan kemampuan yang telah dimilikinya. Akan tumbuh berkembang bersamaan dengan pengembangan potensi nilai cultural yang ada dalam masyarakat. Dalam keterkaitan tersebut dapat mengangkat potensi sosiokultural berarti juga memberikan kesempatan kepada masyarakat untuk menata dirinya sendiri ke arah yang lebih baik.

4. Disiplin: suatu tindakan tertib dan patuh pada berbagai ketentuan dan peraturan yang harus dilaksanakannya.

5. Kerja keras: suatu upaya yang diperlihatkan untuk selalu menggunakan waktu yang tersedia untuk suatu pekerjaan dengan sebaikbaiknya sehingga pekerjaan yang dilakukan selesai pada waktunya.

6. Kreatif: berpikir untuk menghasilkan suatu cara atau produk baru dari apa yang telah dimiliki.

7. Peduli lingkungan: suatu sikap dan tindakan yang selalu berupaya mencegah kerusakan pada lingkungan alam di sekitarnya, dan mengembangkan upaya-upaya untuk memperbaiki kerusakan alam yang sudah terjadi.

\section{PENUTUP}

Peran perempuan dalam mata pencaharian hidup, dalam kaitannya dengan budaya maritim Waropen dituntut dapat mengerjakan berbagai pekerjaan untuk menujang kelangsungan hidup keluargannya dan masyarakat sosial lainnya. Dalam adat istiadat suku Waropen, Perempuan bertanggung jawab untuk memenuhi kebutuhan sandang dan pangan keluarga. Berdasarkan hal tersebut maka ada pembagian kerja yang jelas diantara lakilaki dan perempuan, sesuai dengan adat istiadat yang berlaku di dalam kehidupan mereka.

Masyarakat Waropen merupakan masyarakat yang dalam perekonomian sangat tergantung dan dipengaruhi 
oleh alam lingkungannya, yang masih menunjukan pola kehidupan tradisional. Keadaan lingkungan alam Waropen telah mempengaruhi sistem mata pencaharian mereka. Ada 3 macam mata pencaharaian perempuan Waropen yaitu, meramu sagu, menangkap kepiting, mengumpulkan bia atau kerang dan bercocok tanam sebagai mata pencaharian tambahan.

Dalam mengeksploitasi alam lingkungannya, perempuan Waropen yang berada di Distrik urei-Faysei menciptakan berbagai macam peralatan dalam tingkat teknologi yang masih sangat sederhana untuk memudahkan mereka dalam aktivitas mencari. Alatalat tersebut antata lain: alat untuk menokok sagu, alat untuk menangkap kepiting dan mengumpulkan kerang, serta alat-alat bercocok tanam. Aktivitas mata pencaharian perempuan Waropen biasanya secara perorangan atau peduli lingkungan.

keluarga batih, namun demikian untuk kegiatan ritua-ritual adat biasanya dilakukan secara bersama-sama kerabat. Dalam aktivitas tersebut ada pembagian tugas yang jelas antara lakilaki dan perempuan, disamping itu juga tetap menjaga keseimbangan dengan alam lingkungannya, mereka harus mentaati aturan-aturan adat yang ada.

Peran perempuan kaitannya dengan budaya maritim, perempuan Waropen megikuti sistem pengetahuan waktu (wado), bintang (uma), angin (ghama), pengetahuan-pengetahuan tersebut bermanfaat untuk kepentingan pelayaran lokal dan kegiatan sami (kegiatan pencaharian). Dari peran perempuan dalam budaya maritim di Waropen termuat nilai-nilai budaya yang berguna bagi kehidupan, terutama bagi generasi penerus bangsa yaitu nilai religius, gotong royong atau kerja sama, kemandirian, disiplin, kerja keras, kreatif, 


\section{DAFTAR PUSTAKA}

Berry John W, dkk. 1999. Psikologi Litas Budaya : Riset dan Aplikasi Jakarta: PT.Gramedia Pustaka Utama.

Haviland, William A. 1988. Antropologi 2 (diterjemahkan oleh R.G Soekadijo). Surakarta: Penerbit Erlangga.

Maryone, Rini. 2007. Sistem Mata Pencaharian Etnis Waropen di Distrik UreiFaisey dan Distrik Waropen Bawah. Balai Arkeologi Jayapura.

Modouw, Yektiningtyas Wigati. 2008. Herlaehili dan Ehabla. Fungsinya dan Peran Perempuan dalam Masyarakat Sentani Papua. Jogjakarta: Adicita Karya Nusa.

Redaksi, Dewan 2008. Metode Penelitian Arkeologi. Jakarta: Pusat Penelitian dan Pengembangan Arkeologi Nasional.

Revassy, L dkk. 1982. Sistem Ekonomi Tradisional sebagai Perwujudan Tanggapan Atif Terhadap Lingkungan. Jayapura: Kanwil Departemen Pendidikan dan Kebudayaan.

Sanggenafa, Naffi. 1993. Masyarakat Waropen di Pantai Timur Teluk Cenderawasih dalam Irian Jaya Membangun Masyarakat Majemuk. Jakarta: PT Djambatan.

Sanggenafa, Naffi. 1993. "Suku Bangsa Waropen, sebuah Etnografi", Etnografi Irian Jaya, Panduan Sosial Budaya, Buku I, Kelompok Peneliti Etnografi Irian Jaya.

Soejono, R. P. 2000. Aspek-Aspek Arkeologi Indonesia No 5. Jakarta: Departemen Pendidikan Nasional Pusat Arkeologi.

Susanti, B.M. 2000. Penelitian tentang Perempuan dan pandangan Androsentris ke Prespektif Gender dalam Ekspresi dari Bias Lelaki Munuju kesetaraan gender. Yogyakarta: Lembaga Penelitian Institut Seni Indonesia. 